\title{
Cultural Anthropology as an Approach for Vernacular Architecture Case Study: Gharb Soheil, Nubia, Egypt
}

\author{
Ranad Bahaa Afifi ${ }^{1}$ and Mohamed Thabat Ismail ${ }^{2}$ \\ ${ }^{1}$ Assistant Lecturer, Modern Academy for Engineering and Technology and Ph.D., Students, Faculty of Engineering, \\ Cairo University, Egypt. ORCID: 0000-0001-5932-2678 \\ ${ }^{2}$ Lecturer, Modern Academy for Engineering and Technology, Egypt.
}

\begin{abstract}
Architecture for humanity represents the finest of the new breed of architectural leadership; where the architect's mission exceeds the borders of finding the proper dimensions and placements within architectural space, to the stage of understanding a person and his behavior within this space. Cultural Anthropology is the median of the relation between architecture and human beings; as it studies the social, nonmaterial and material lives of contemporary and historical human societies, assigning certain cultural determinants for architect's work so that this context is embodied in architecture to get sustainable buildings through the perspective of culture and society, no matter time invested in comparison with mistakes can be prevented.

Thus, the research aims to use an anthropological perspective to contemplate appropriate architecture and design for different cultural environments to cope with rapid cultural transformation and to introduce new approaches that can be applied to the design process. It aims at encouraging the attempt of returning to the vernacular architecture of different societies and its vocabularies, which is architecture by/for people, depending on their culture, needs, and localities. Moreover it aims to apply vernacular vocabularies in modern communities through an anthropological perspective to create affordable architecture that expresses the identity of the society it belongs to and serves the culture of people who will live there.
\end{abstract}

Keywords: Culture, society, Anthropology, vernacular architecture, Architecture of people.

\section{INTRODUCTION}

House forms are usually linked to sociocultural conditions, as special patterns, ornaments, and colors which are related to certain cultural behavior for a certain group of people. This is the objective of cultural anthropology to interpret and explain different cultures of people all over the world and their attitudes towards their culture and it's reflection on their life. The anthropologist's task becomes a work of translation and to immerse himself in the reality by participative observation and dialogue, to make it understandable for other sectors of society, so that anthropology becomes a median between the architect and inhabitants. These are two characteristics of the same spatial reality but from two different points of view.
Vernacular architecture is an essential proof for the reflection of the culture of a specific group of humans who have the same culture and lifestyle on buildings, presented in a material, a color scheme, an architectural language for the urban framework. Moreover, it is energy efficient and sustainable. So, if vernacular architecture strategies are applied to modern design, it can ideally achieve sustainable and wholly self- sufficient buildings, so architects should be astonished to determine how people built it without any techniques; as it was built by empirical builders without the involvement of professional architects. Furthermore, it is still alive and valuable; as it reflects the human building heritage and confronts a lot of threats to continue its existence along with rapid cultural interaction, technologies, and human needs [1].

Nowadays, Architects are concerned with aesthetic and technical aspects in planning, designing, and construction of buildings, neglecting the cultural aspects of each society in which the project is executed. This leads to creating a gap between the architect and people, so the main objective of this paper is to introduce anthropological guidelines for the design of building projects, helping architects to understand the beliefs and culture of the people using it to satisfy their housing needs. This is applied through studying Cultural Anthropology and correlating its aspects with architecture; as it is from the disciplines which study human profoundly.

\section{BACKGROUND}

II.I Cultural Anthropology: it is a branch of anthropology that studies the culture and lifestyle of people in different ecological and geographical locations. It studies human's traditions, norms, arts, religions and beliefs, literature, customs, and science. It explains similarities and differences between different communities and societies [2].

II.II Vernacular Architecture: First used in architecture in 1964 in "architecture without architects" book, then it becomes widespread in other alternative vocabularies such as Ancestral architecture/Indigenous architecture/ Ethnic architecture/ Eco-friendly architecture. Paul Oliver defined vernacular architecture in "the encyclopedia of Vernacular Architecture of the World" in 1987; as architecture designed by people not professional architects, which integrates between dwellings and other buildings according to the environmental context and available resources to satisfy people's needs by respecting values, traditions and other socio-cultural aspects [3]. 


\section{II.II.I Characteristics of Vernacular Architecture}

There are some distinctive characteristics for vernacular architecture that assist in distinguishing it from other buildings, as the following [4]:

- Vernacular architecture is a product of lifestyle, customs, and culture.

- Often built by people who use it or not by professional architects.

- Construction and materials depend on local resources and constraints.

- Buildings blend with the landscape.

\section{II.II.II Types of vernacular architecture}

Vernacular buildings have different types and designs incorporated with their functional requirements to satisfy people's needs. Functions can be explained in the following:

- Rural Vernacular Architecture: It includes dwellings and production units, as stables, piggeries, silos, and barns. Buildings are restricted by local resources, climate (structure, wall thickness, materials, and orientation of buildings.), environmental and social factors (layout according to each region), and the visual impact of the landscape [5].

- Domestic vernacular Architecture: it includes nomadic dwellings which must be from light structures and local materials, it can be bamboo, palms, or animal leather. Permanent dwellings Buildings for accommodation in certain places. It must be from heavy structures and materials [6].

- Industrial and commercial: It includes arts and crafts workshops, factories, and shops. Industrial buildings vary according to the main industries and crafts practiced in each region, which depend on the local resources and tools used in working; where some vernacular regions depend on the weaving and textile industry, other regions depend on accessories or pottery industry, others depend on herbs and others depend on forging, carpentry and other types of industries corresponding to resources that each region is rich with [7].

\section{II.III Impact of Anthropological studies on Vernacular Architecture}

Some architects put hypotheses to assure the relation between studying the culture of people and their architecture, to create a familiar environment for them to live in, and to resurrect people's customs, traditions, folklore, arts, and all elements of their culture over the time.

- Amos Rapoport Hypotheses: Amos Rapoport studies the relationship between vernacular dwellings and culture through looking to the form of buildings and the functional relations between their spaces as a result of people's vision to the ideal life of their environment, that reflects many sociocultural forces, including religion and beliefs, family and clan structure, social relations between individuals and social their needs [8].

- Christopher Alexander Hypotheses: described the unselfconscious design as a "bricolage"; which means the design is achieved by the users. Unselfconscious design is design without designers. It is the common form of design in primitive and vernacular societies, in which design professions do not exist. The unselfconscious design has two features which are traditions and directness of response [9].

- Enrico Guiodoni Hypotheses: describes the architecture as a product of history further than geography; as it is the result of cultural factors work in correlations and Chronological sequence. He also states that it is important in understanding the primitive architecture to appreciate that every culture helps in explaining why objects and elements are in the form they are, which means that architecture is the physical form of culture. Influences on the primitive built environment are ownership and settlement, myth and symbolism, and human race [10].

- Popular anthropological studies

Anthropological studies show the relationship between man and the built environment. Also it helps builders to understand the beliefs and values of the people who utilize the project. They have to observe the elements of the culture which drive the people's way of life and ultimately influence their choices with the buildings which they inhabit.

- Impact of Cultural studies on Built Environment of China and Africa: They are divided into a large number of tribes having their own identity and culture applied to all their lifestyles. Also there are mutual cultural connections between them; where Africa is a host of three Chinese cultural centers in Mauritius, Egypt, and Benin. There was early African immigration to China. Most of the African immigrants are concentrated in "Gaungzhou" with an estimated number of 20,000 . This area became known by "Little Africa" and "Chocolate City". On the other side, early Chinese immigration to the African continent started in 1724; a few Chinese convicts were brought as laborers to South Africa from the Dutch East Indies [11].

- Western anthropological studies: Many cultural and anthropological studies appeared in the nineteenth century and various methodologies of research and field data gathering. Most of these studies were applied to African regions due to European colonialism like Winifred Blackman's study to Upper Egypt, Hans Alexander Winkler's study to Egyptian countryside, and Anthropological studies for Ascoli Piceno city (Italy) [12].

- Egyptian anthropological studies: Most of the cultural and anthropological studies in Egypt were made when people began to understand their heritage and the variance of culture forms along with time. Most of these studies were prepared by "Social research center", which is associated with "Ministry of social affairs", and also by the research centers associated with the Egyptian universities like Anthropological study of Nubia, Anthropological study of Izbat Tunis (Al-Fayoum), and "Timothy Mitchell" anthropological Criticism to Hassan Fathy's attempt in Upper Egypt [13]. 
International Journal of Engineering Research and Technology. ISSN 0974-3154, Volume 13, Number 9 (2020), pp. 2165-2176 (c) International Research Publication House. https://dx.doi.org/10.37624/IJERT/13.9.2020.2165-2176

Table 1. Impact of cultural Anthropology's studies on vernacular Architecture

\begin{tabular}{|c|c|c|c|c|c|c|c|c|c|c|}
\hline \multirow{3}{*}{\multicolumn{3}{|c|}{ Case Study }} & \multicolumn{8}{|c|}{ Impact of cultural Anthropology's studies on Architecture } \\
\hline & & & \multicolumn{8}{|c|}{ Cultural } \\
\hline & & & 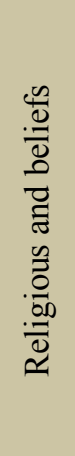 & 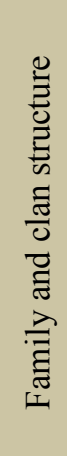 & 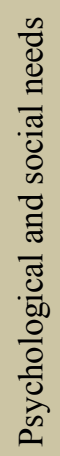 & 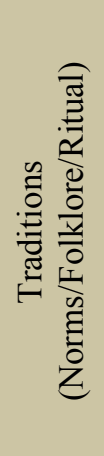 & 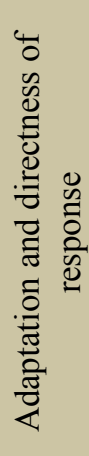 & 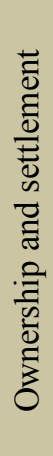 & 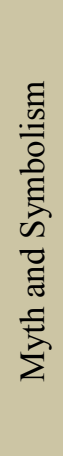 & 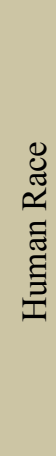 \\
\hline \multicolumn{11}{|c|}{ Architectural } \\
\hline \multirow{10}{*}{\multicolumn{2}{|c|}{ 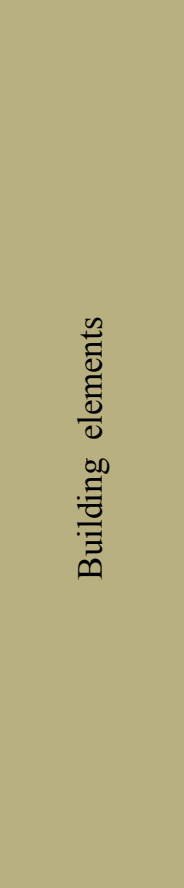 }} & Plan & & & & & & & & \\
\hline & & Facade & & & & & & & & \\
\hline & & Materials & & & & & & & & \\
\hline & & New spaces & & & & & & & & \\
\hline & & Structure & & & & & & & & \\
\hline & & Landscape & & & & & & & & \\
\hline & & Orientation & & & & & & & & \\
\hline & & Ornaments & & & & & & & & \\
\hline & & Layout & & & & & & & & \\
\hline & & Symbols & & & & & & & & \\
\hline \multirow{7}{*}{ 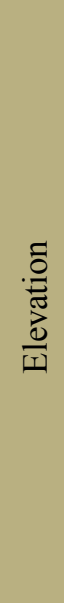 } & \multirow{4}{*}{$\begin{array}{l}\stackrel{\infty}{\Xi} \\
\stackrel{\Xi}{\tilde{\Xi}} \\
0\end{array}$} & Entrance & & & & & & & & \\
\hline & & Windows & & & & & & & & \\
\hline & & $\begin{array}{l}\text { Ventilation } \\
\text { openings }\end{array}$ & & & & & & & & \\
\hline & & Perforated units & & & & & & & & \\
\hline & \multicolumn{2}{|c|}{ Color of elevation } & & & & & & & & \\
\hline & \multicolumn{2}{|r|}{ Heights } & & & & & & & & \\
\hline & & ig \& Decoration & & & & & & & & \\
\hline
\end{tabular}




\section{ANALYTICAL STUDY}

It is performed on "Garb Soheil" in Egypt. It is in the cultural realm "North Africa", so it shares common cultural aspects, which have impacts on the architecture.

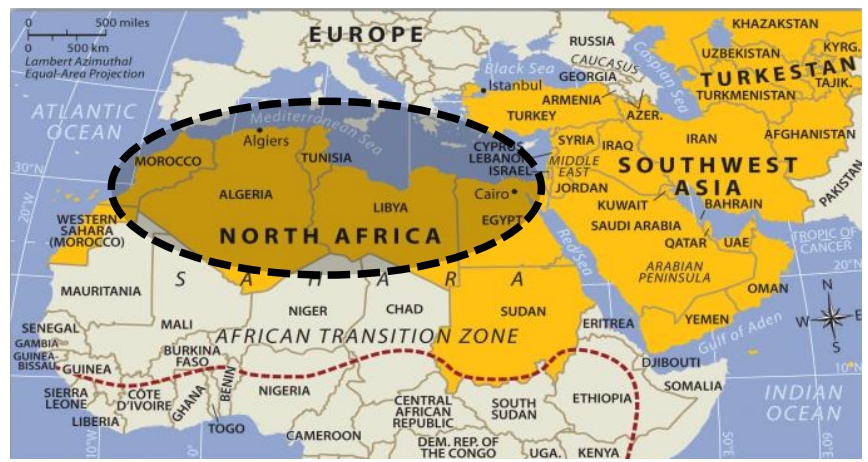

Fig. 1. North Africa cultural realm [14]

\section{III.I Gharb Soheil, Egypt:}

Vernacular architecture of old Nubian society is what affords its valuable character than other traditional Egyptian societies. Gharb Soheil is considered as a strong example for old Nubian villages before displacement and resettlement. This village faced all the obstacles especially the time and the place; it remains stable on the western banks of the Nile without being sunk by "The high dam".

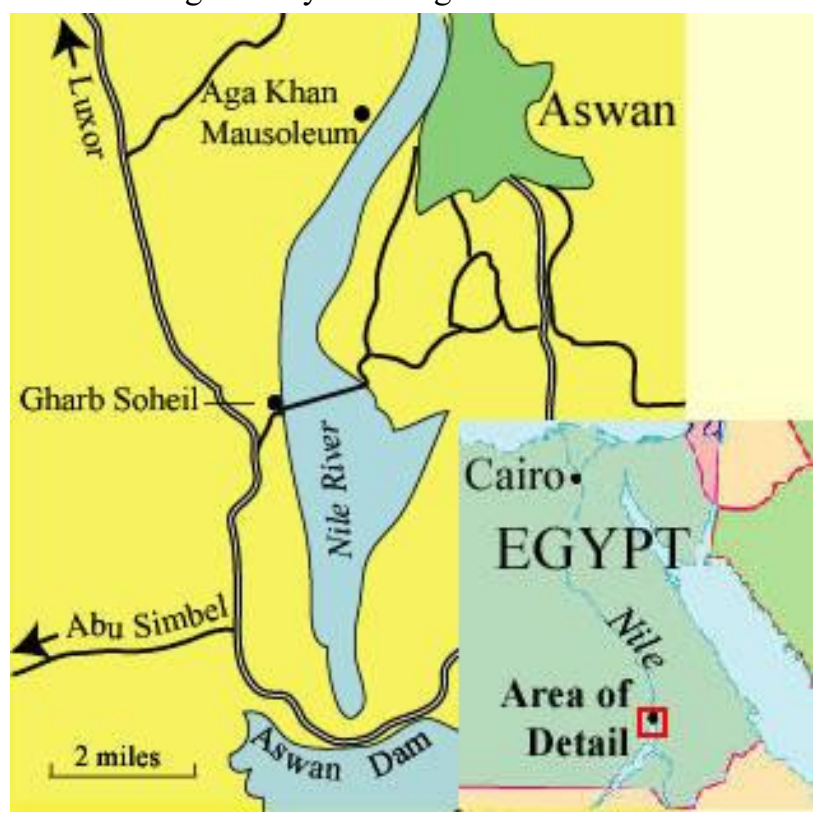

Fig. 2. North Africa cultural realm [15]

Gharb soheil was chosen for the following criteria:

- It was not affected by the construction of the High Dam in the 1960s. The village remained in its original environment; it was therefore assumed that cultural identity still survives.

- It was recently chosen by the tourism business to put Nubian villages and its culture on the map of tourism destinations around Aswan.

- It does not have any specific archaeological monuments or in its surroundings. It was therefore an opportunity to explore how an ordinary Nubian village would make use of their traditions in all lifestyles.

\section{III.I.I Impact of Anthropological determinants on Architecture of Gharb Soheil:}

- Religion and beliefs: Religion and beliefs in Nubia affect their dwellings in ornaments, orientation, and arrangement of spaces, the addition of specific spaces, or even the chosen colors. Most of the paintings and decorations on the homes have religious connotations. Also it can affect the form of their entrances and emphasizing the gateways.

$>$ Cleanliness and purity [16]:

- Locating bathrooms outside the dwellings.

- Animal stable outside the house.

- Inner courtyard covered by sand.

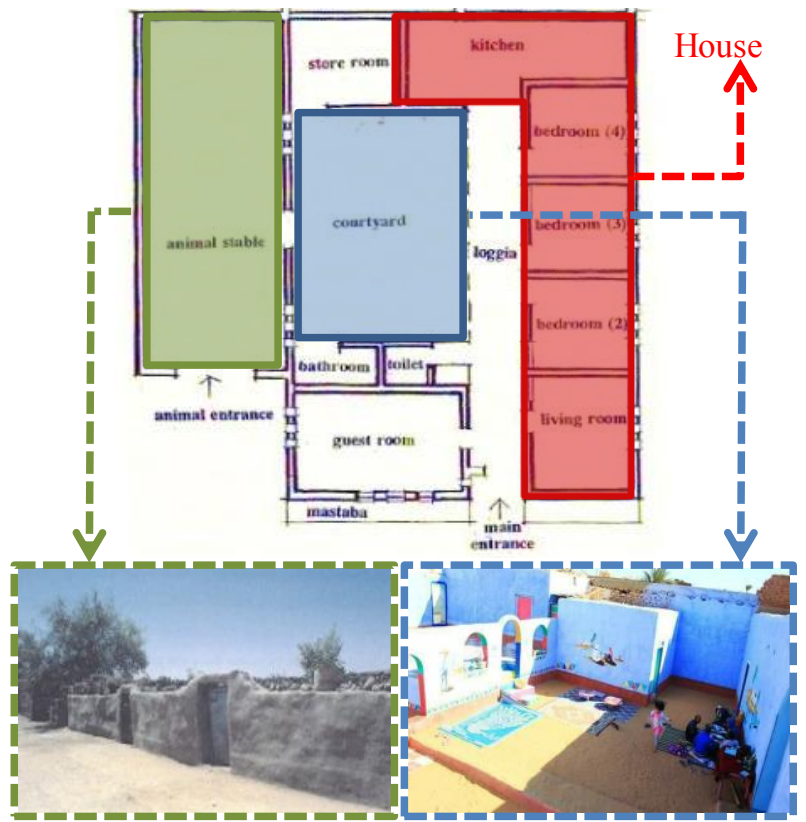

Fig. 3. Cleanliness in Nubian House Source: Researcher

Emphasizing the religious identity:

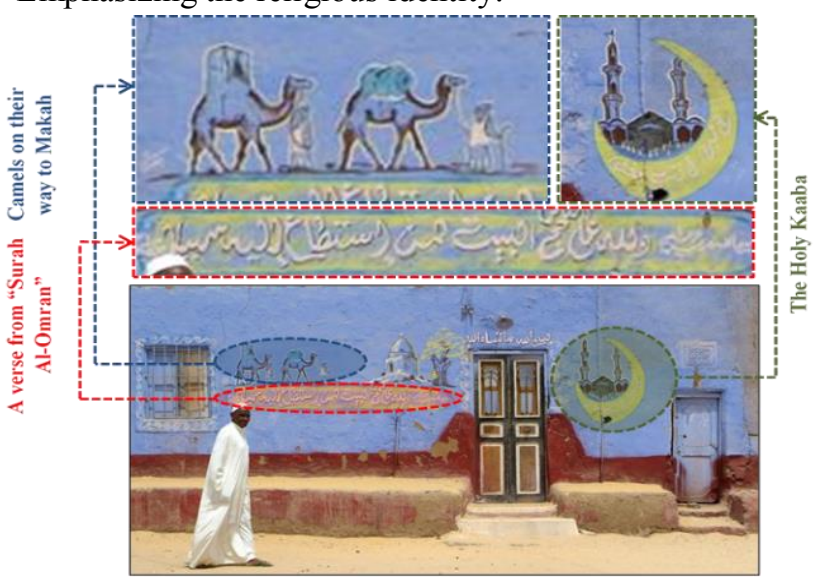

Fig. 4. Hajj issues on his dwelling façade. Source: Researcher 
$>$ Belief in envy [17]:

- They put hanging plates on the top of their houses in geometrical forms as they are the eyes of people.

- They use eye and "Kaf-Fatima" symbols as protection from envy.

- Mummified animals like crocodiles, rodents, or birds, which refers to the power, so that people be aware of looking and envying them. Also Horns protect animals from enemies so they protect houses from envy.

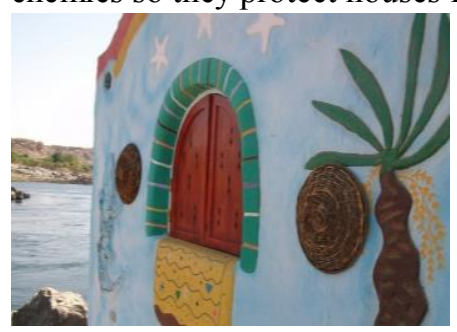

Fig. 5. Hanged Plates Source: Researcher
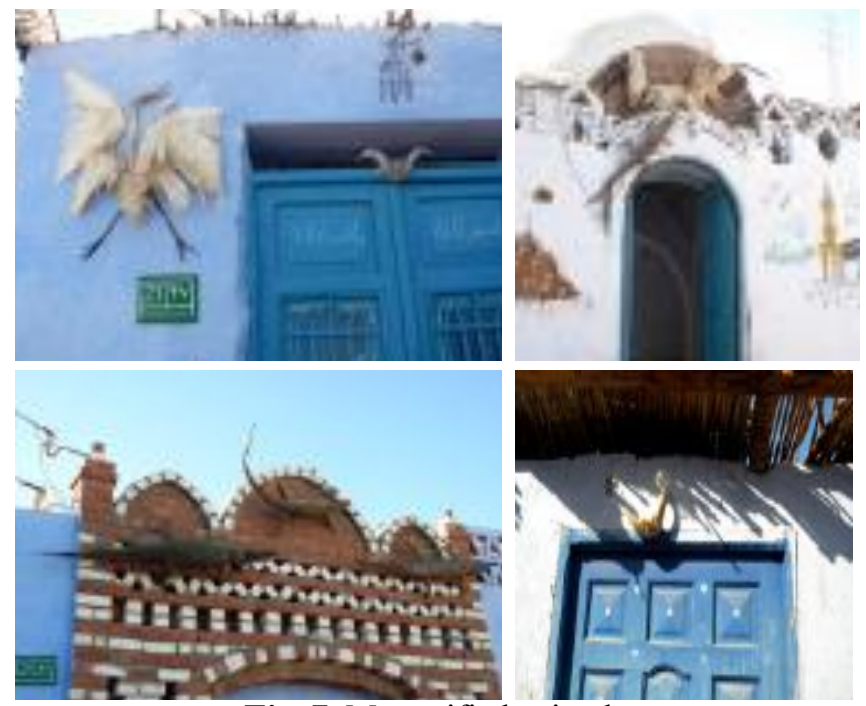

Fig. 7. Mummified animals

Source: Researcher

$>$ Sacredness of home [16]:

Entrances and the gradient elevated parts that surround the entrances, and also the lack of openings.

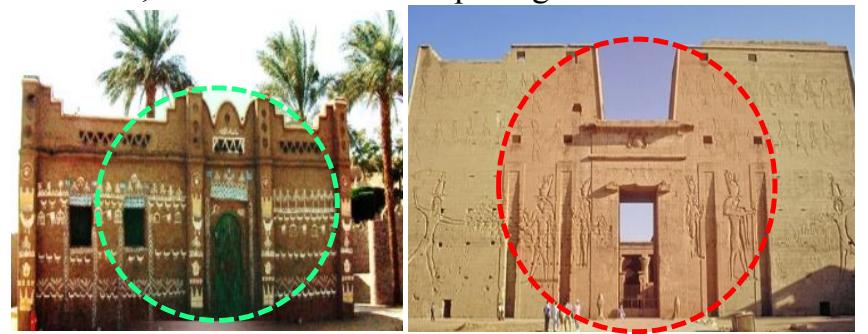

Fig. 8. Horus Temple and Nubian House Source: Researcher

$>$ Sanctification of ancestors [18]:

Groves of a certain geometrical shapes which is like architectural depressed ornaments, which is called "AlMukharmat"; and the purpose from these groves is to form spaces for the spirits of ancestors to live in.

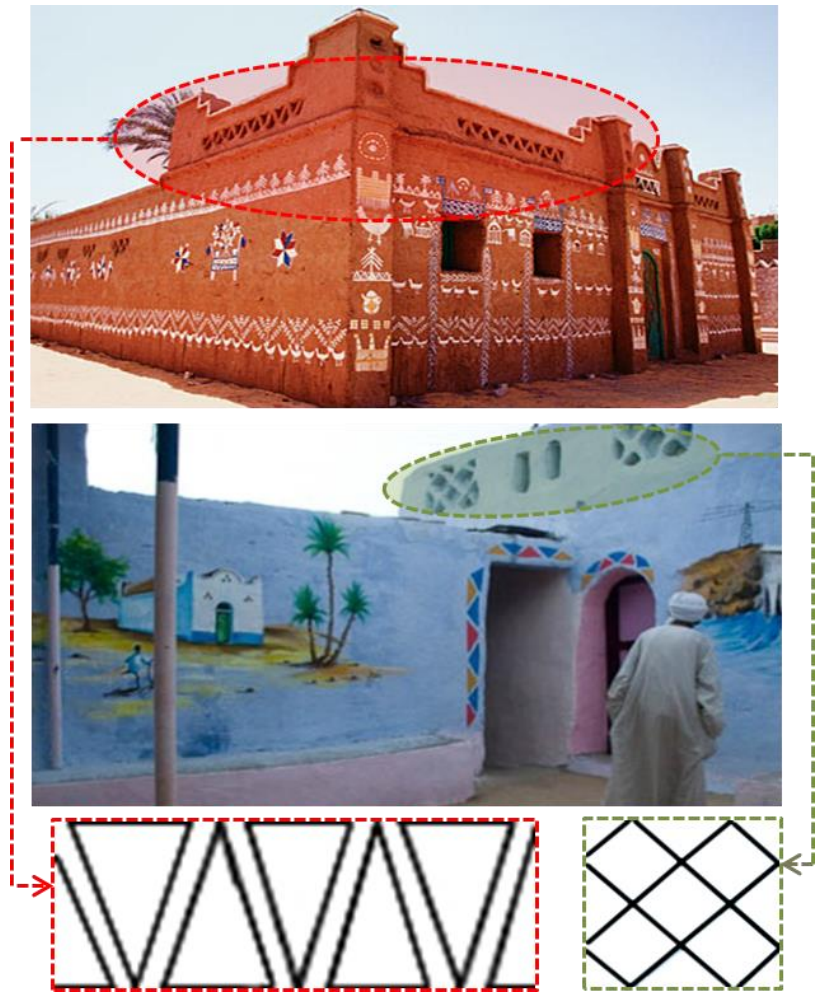

Fig. 9. Mukharmat on the top of Nubian House Source: Researcher

$>$ The sanctification of the Nile River [19]:

- The orientation of all main entrances to Nile direction.

- Using curved lines and zig-zag horizontal lines which refers to the Nile's flow.

- Using blue painting and also white lime painting on the facades, which refers to the Nile during the flow.

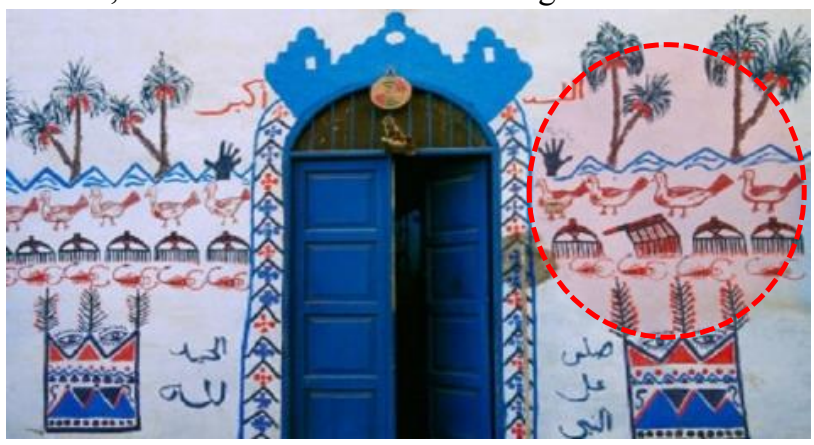

Fig. 10. Zig-zag lines refer to the Nile's flow Source: Researcher

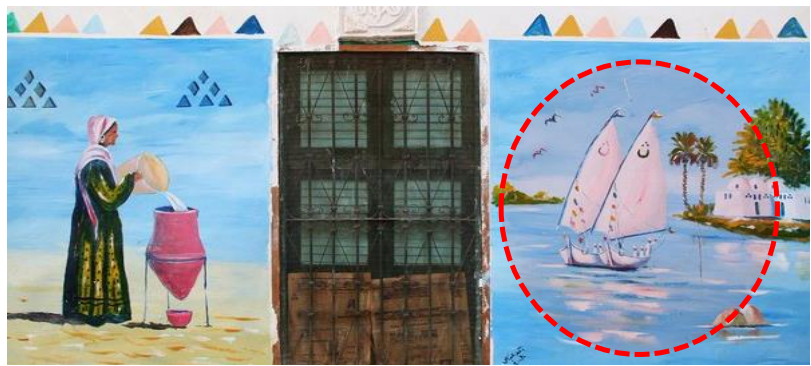

Fig. 11. Nile River painting on a façade of Nubian dwelling

Source: Researcher 
International Journal of Engineering Research and Technology. ISSN 0974-3154, Volume 13, Number 9 (2020), pp. $2165-2176$

(c) International Research Publication House. https://dx.doi.org/10.37624/IJERT/13.9.2020.2165-2176

$>$ Power [16]:

Power in Nubian culture represents their armor from devils, bad luck, and evil people. It exists in many forms and symbols they believe in its power according to their popular stories and cultural heritage. These symbols are rooster, scorpion, and crocodile.

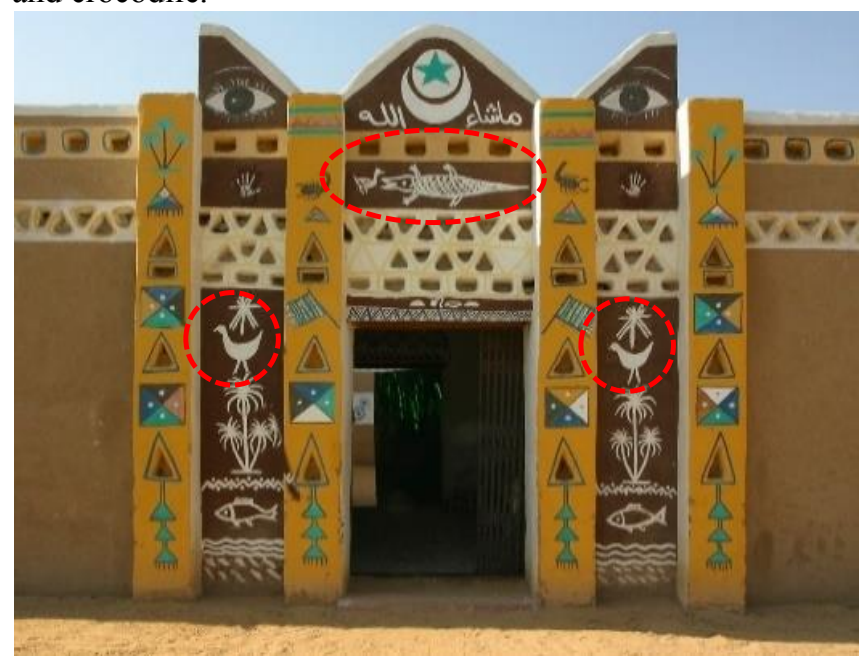

Fig. 12. Rooster and crocodile on a façade of Nubian dwelling

Source: Researcher

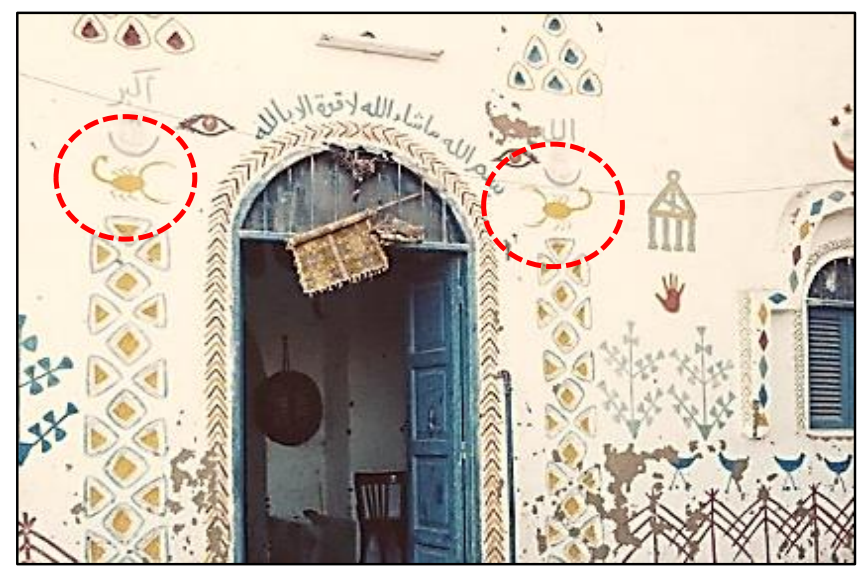

Fig. 13. Scorpion on a façade of Nubian dwelling Source: Researcher

- Family and Clan structure: All forms of interaction between family members, which extend also to a strong interaction between tribes and society, have a strong reflection on their architecture, design, and spaces.

$>$ Social familial interaction [16]:

An open courtyard is an indication of a strong relation between family members.

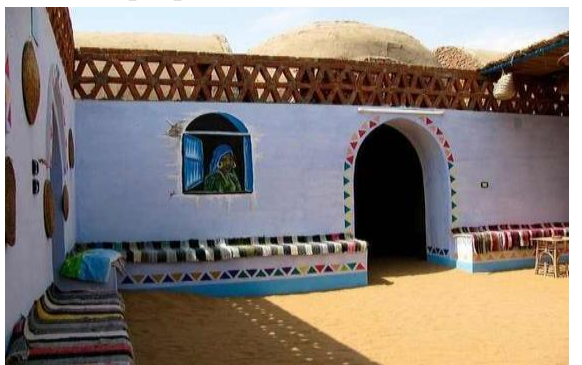

Fig. 14. Open court Source: Researcher
$>$ Social tribal interaction [19]:

- Al-Madyafa: a room where all guests stay in to visit and sit with people in the house.

- Platform (Mastaba): a platform in front of the entrance of the house, where the men met and sit together for talking and gathering.

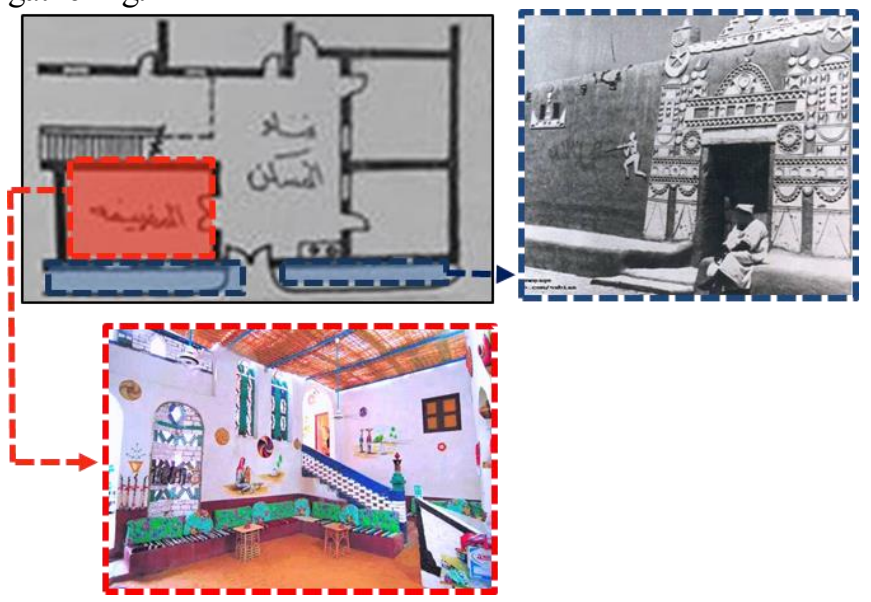

Fig. 15. Madyafa and Mastaba in Nubian house [25]

$>$ Presenting women and girls proficiency

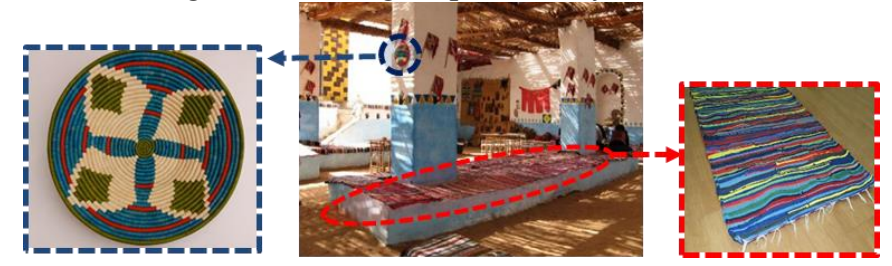

Fig. 16. Decorative items Source: Researcher

Independence and believing in their selves [16]: It is applied in architecture through the "deewani"; where the bride accommodate with her husband in her father's house for seven days in a space called "deewani". Deewani consists of a room, court and kitchen.
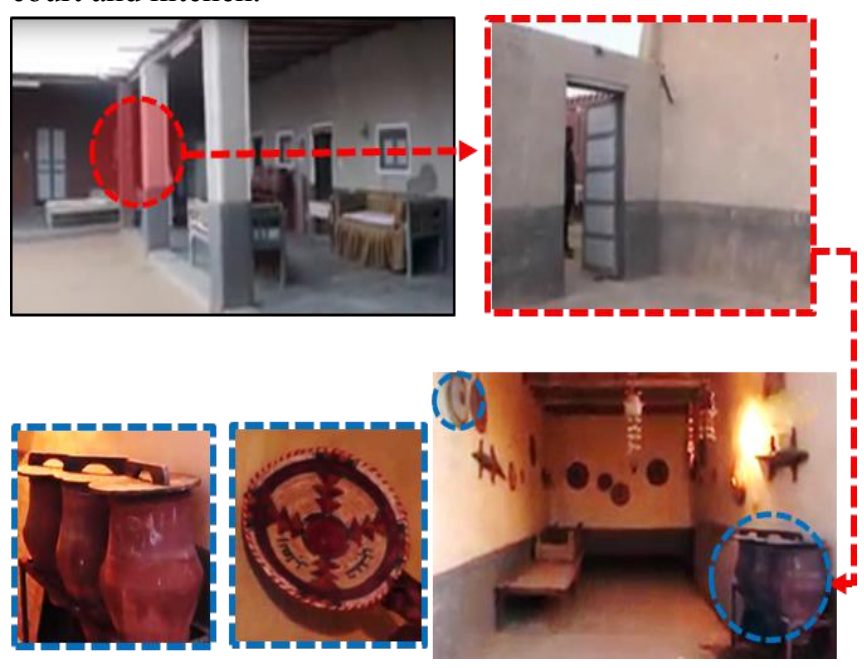

Fig. 17. Deewani in Nubian house Source: Researcher 
International Journal of Engineering Research and Technology. ISSN 0974-3154, Volume 13, Number 9 (2020), pp. $2165-2176$

(c) International Research Publication House. https://dx.doi.org/10.37624/IJERT/13.9.2020.2165-2176

$>$ Reproduction [16]:

- The presence of two water casks at the entrance of the residents, which refers to the first man and woman from which the whole humanity was descended is called "AlMazyara'.

- Using "latch and key" (daba wa moftah) which expresses the intercourse between male and female.

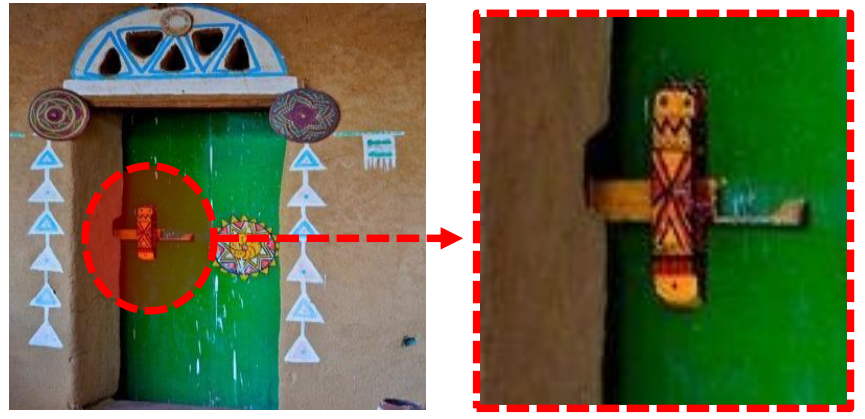

Fig. 18. Latch and key

Source: Researcher

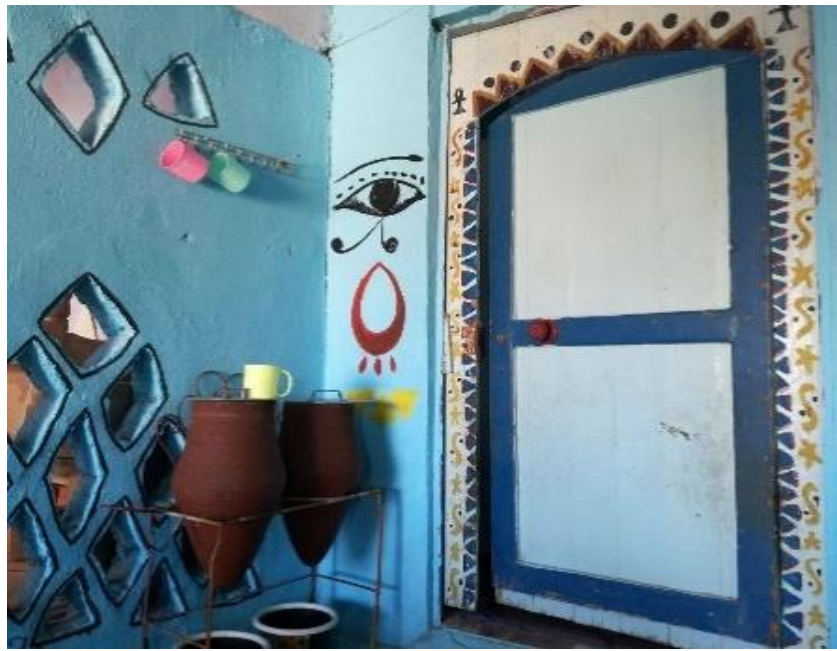

Fig. 19. Mazyara

Source: Researcher

- Psychological and social needs: Nubians tried to satisfy all their needs by applying some architectural and design solution, and also they created some spaces for practicing their psyochological needs like privacy or welcoming people in their houses.

$>$ Safety and Security [17]:

Peace and safety by reducing windows in external walls.

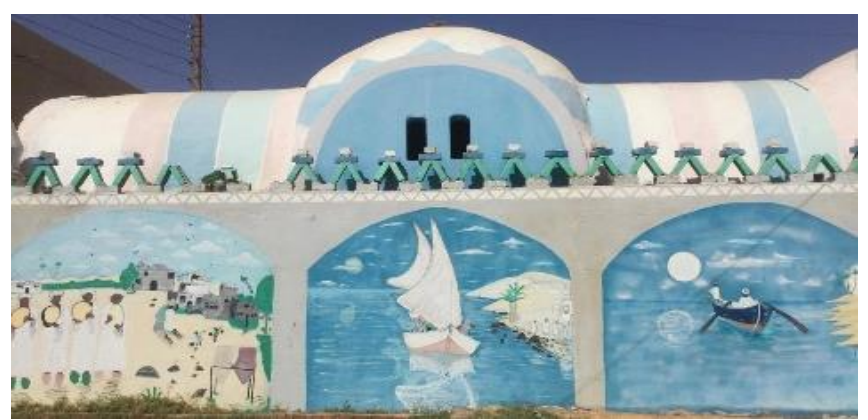

Fig. 20. Few openings on facades Source: Researcher
$>$ Visual privacy [16]:

- Women enter the house away from the main door, where men are sitting on the platform (Al-Mastaba)

- Deewani is isolated from the whole house; as there is a wall separating the open courtyard from the entrance and courtyard of the deewani

- "Al-madyafa" includes an inter wall that prevents guests when they enter the house from seeing the people inside the courtyard.

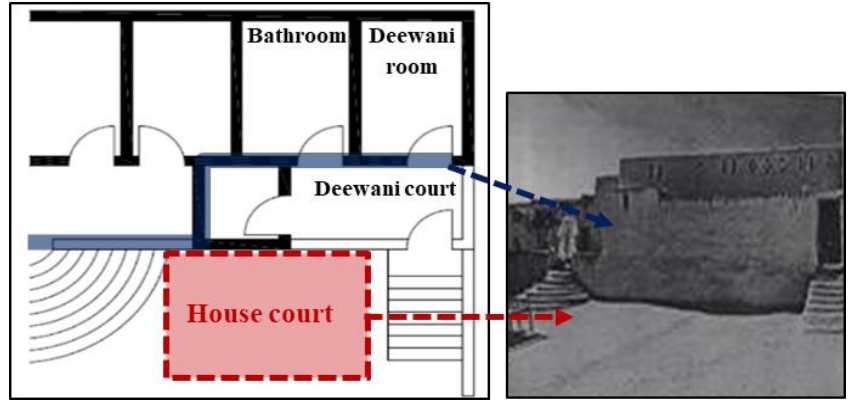

Fig. 21. Separating the deewani from the house's court through a wall [31]

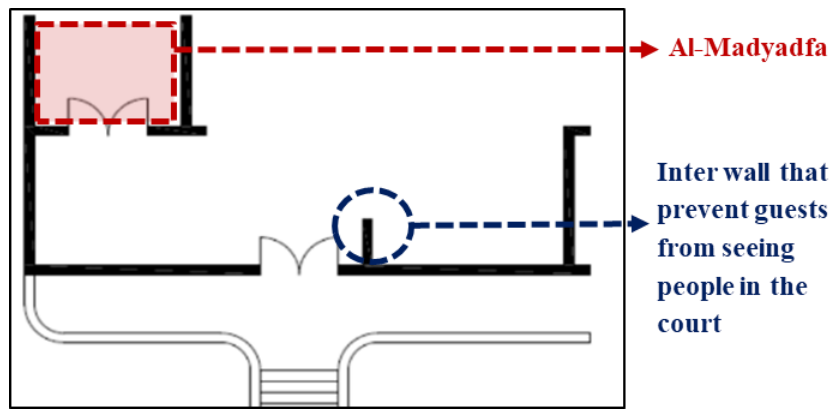

Fig. 22. Inter wall for hiding open court from guest's eyes [31]

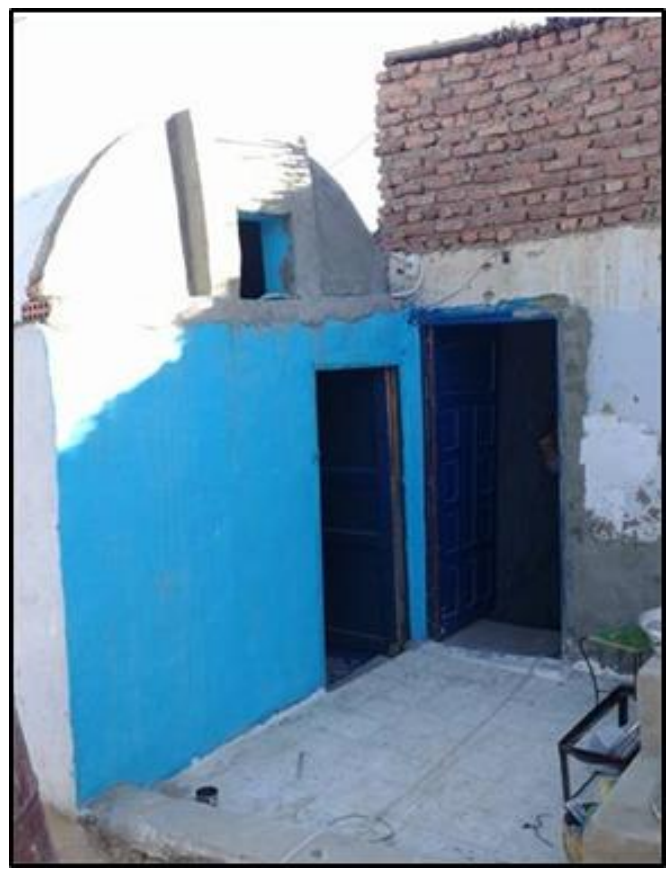

Fig. 23. Women entrance

Source: Researcher 
International Journal of Engineering Research and Technology. ISSN 0974-3154, Volume 13, Number 9 (2020), pp. $2165-2176$

(c) International Research Publication House. https://dx.doi.org/10.37624/IJERT/13.9.2020.2165-2176

$>$ Balance with nature [19]:

- The wideness of the inner courtyard to emphasize the strong interaction of the house with the sky.

- Growing of plants and trees in the inner court, and emphasizing its importance by surrounding it by a wall.

- Street pattern: Streets in Nubian settlements are not straight and always follow the topography of the site that prevents hot air and dust from movement inside the settlement. Streets are narrowed to allow maximum shade and shadow.

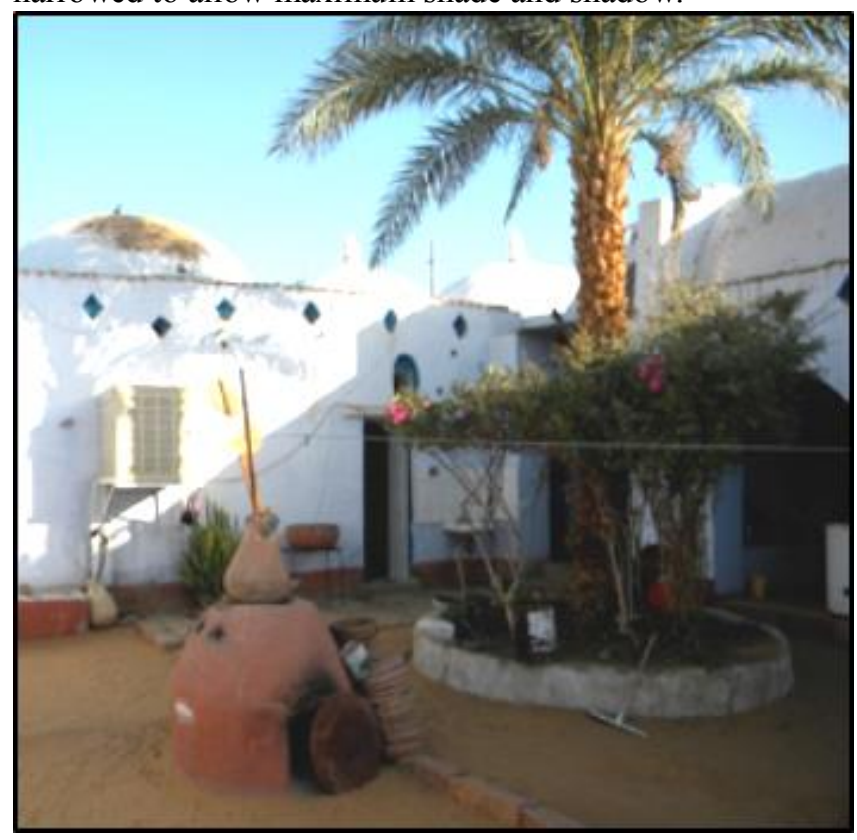

Fig. 24. Palms and trees in the courtyard Source: Researcher

- Traditions: Their strong attachment with their traditions has a strong influence on architecture through the following: $>$ Festivals [17]: "Al-Noba bel Alwan Festival", between 26 June-5 July. coloring and decorating the houses of Nubia.

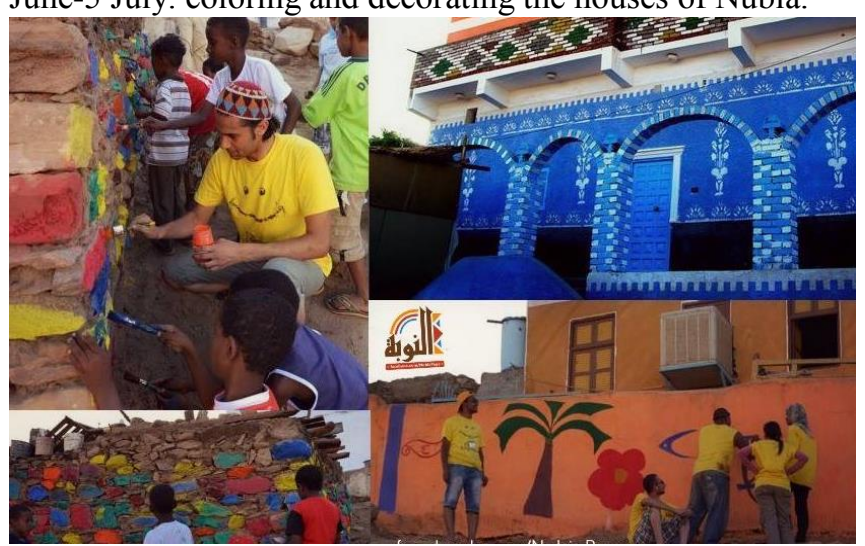

Fig. 25. Coloring houses in festivals Source: Researcher

$>$ Generosity and hospitality [20]:

- "Al-Madyafa": space where guests and foreign people are welcomed. It is found near to the main entrance, and away from people who live in the house.
- Paintings on walls which represent hospitality as the table, plates, and teapot.

- Presence of Mastaba which considered as an external place for sitting with neighbors or visitors
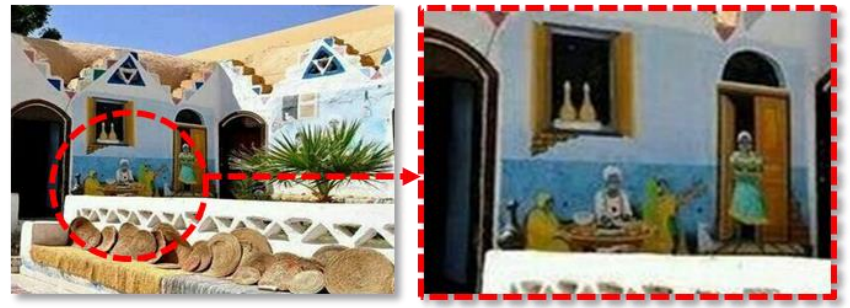

Fig. 26. Paintings represent hospitality on walls Source: Researcher

$>$ Customs and norms [16]:

- Pharaonic and Islamic paintings on Nubian facades.

- Scarification of Nile River like their Pharaonic ancestors.

- Planting on the dead graves.

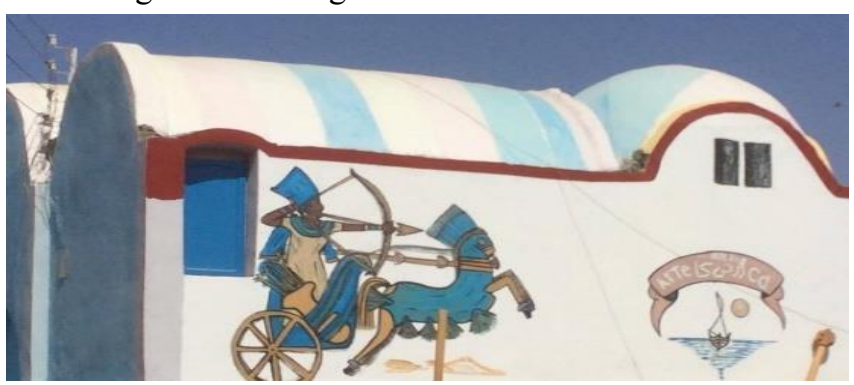

Fig. 27. King Ahmus painted on Nubian façade Source: Researcher

$>$ Crafts [21]: Their crafts like beaded necklaces and accessories, colorful crocheted bags and hats, also some masks and wooden sculptures are sold in small wooden huts, and some buildings are specified for a certain craft to be practiced in, like drawing henna-tattoo for women.
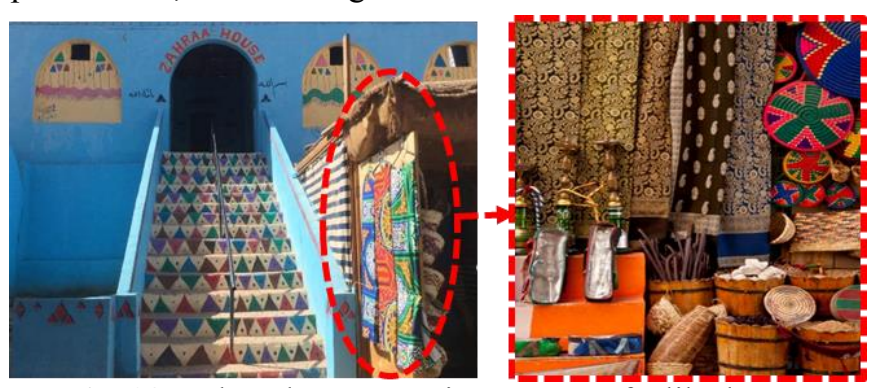

Fig. 28. Zahraa house practice many crafts like henna drawing and selling crafts outside.

Source: Researcher

- Adaptation and directness of response [22]:

- Adaptation: Nubian builders using materials from nature rocks for foundations, earth and water for adobe bricks and mortar. The bricks are standard bricks that are made locally by the people.

- Directness of response:

- Nubian vault; where they built it oriented to north with upper openings to let air rarefy to the court. 
- Lack of windows increases the area of solid walls which help decrease thermal transfer from outer space to inner space.

- Using light colors in painting external walls to reflect sun rays and reduce absorbance of heat.

- Upper openings help good ventilation that they provide access for hot air which rises up and out through upper openings.

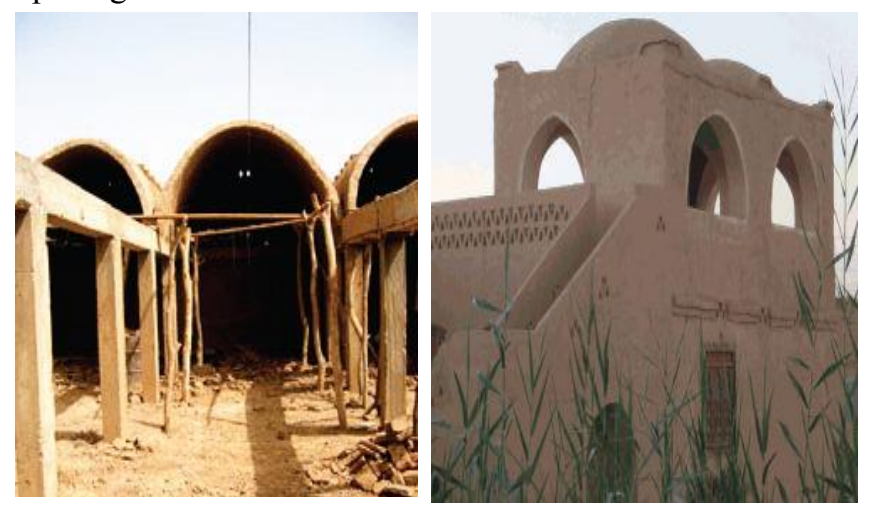

Fig. 29. Nubian vault.

Source: Researcher

- Ownership and settlement [16]: Most houses of Old Nubia are isolated, to achieve privacy. But some are connected by a common wall. The area of the house is large may reach 500 $\mathrm{m} 2$, and it extends horizontally at one level. This meaning is lost after resettlement where houses are connected and share common walls and back to back. Also the houses extend vertically at more levels.

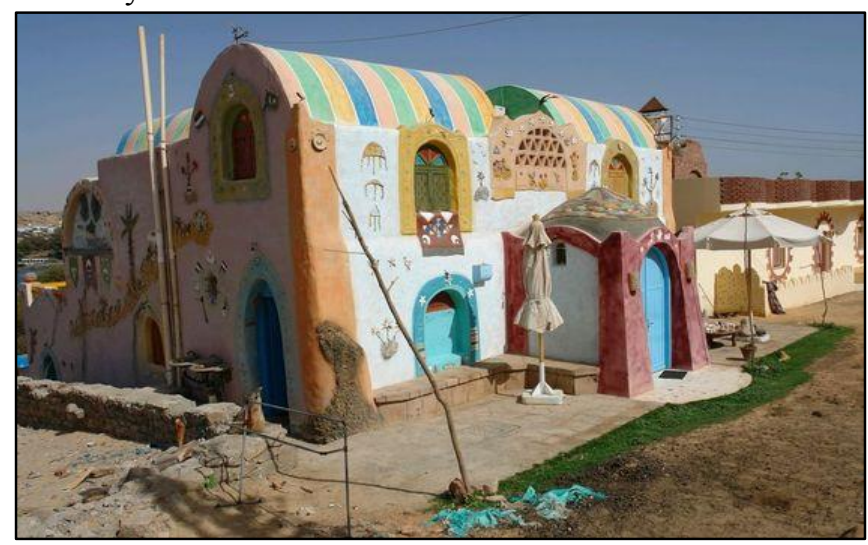

Fig. 30. Isolated houses, Gharb Soheil. Source: Researcher

- Myth and Symbolism [19]:

- Nubian myths like the Nile River and crocodile's popular story.

- Drawing zigzag paintings indicating the Nile River, using blue color indicating the river or white color indicating its purity.

- Teapot symbolize hospitality.

- Palm represents an important use; as the wicker baskets and plates.

- Casks (Mazyara): First male and female in the universe.

- Ferforge windows in madyafa: Protection from eyes of guests.
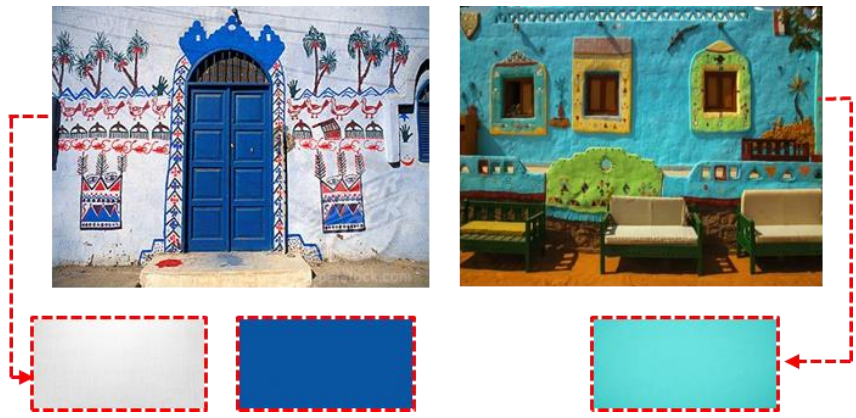

Fig. 31. Blue and white color, and zigzag line on Nubian façade

Source: Researcher

- Open courtyard: family interaction.

- Human race [23]: Old Nubia was divided into three district groups, each with its own language and heritage:

- The Kanzi (Kounuz) area lay on the north. Gharb Soheil still remains in this Area.

- The Arab district lay in the middle.

- The Fadidja district which extends to the Sudanese borders.

- Nubia was composed of 42 administrative areas called nahiat, each governed by an "Umda", they were in turn divided into small communities called "El-Naga"".

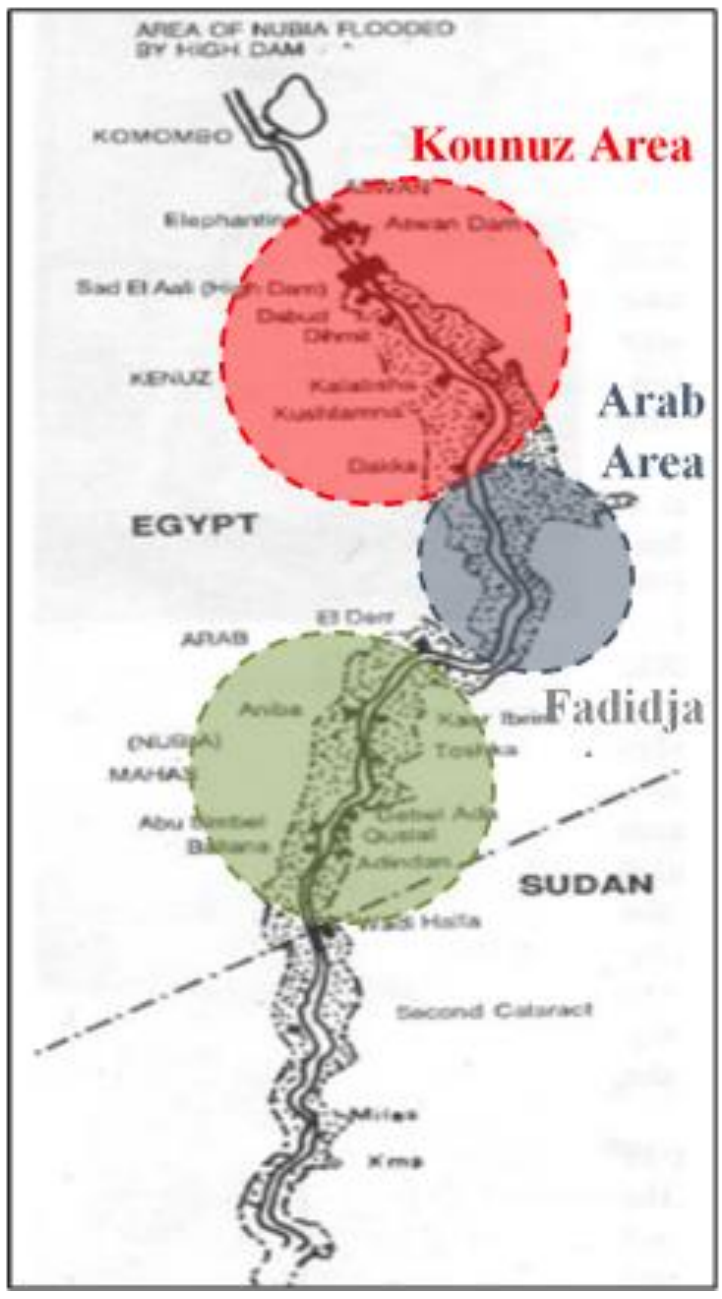

Fig. 32. Groups in Old Nubia [40] 
International Journal of Engineering Research and Technology. ISSN 0974-3154, Volume 13, Number 9 (2020), pp. $2165-2176$

(c) International Research Publication House. https://dx.doi.org/10.37624/IJERT/13.9.2020.2165-2176

Table 2. Impact of cultural Anthropology's studies on vernacular Architecture of Gharb Soheil

\begin{tabular}{|c|c|c|c|c|c|c|c|c|c|c|}
\hline \multirow{3}{*}{\multicolumn{3}{|c|}{ Case Study }} & \multicolumn{8}{|c|}{ Impact of cultural Anthropology's studies on Architecture } \\
\hline & & & \multicolumn{8}{|c|}{ Cultural } \\
\hline & & & 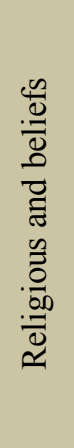 & 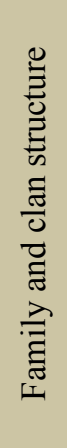 & 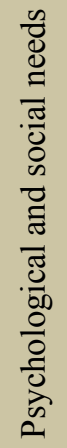 & 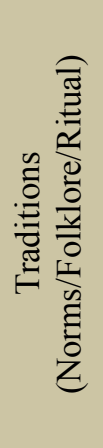 & 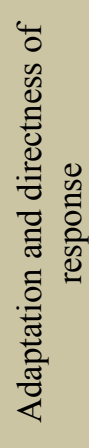 & 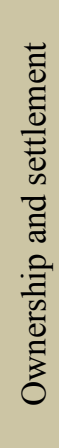 & 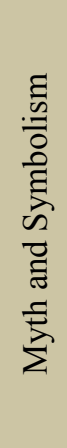 & 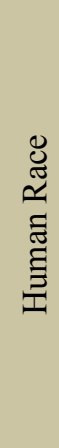 \\
\hline \multicolumn{11}{|c|}{ Architectural } \\
\hline \multirow{10}{*}{\multicolumn{2}{|c|}{ 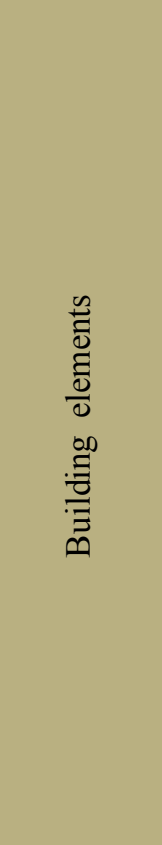 }} & Plan & & & & & & & & \\
\hline & & Facade & & & & & & & & \\
\hline & & Materials & & & & & & & & \\
\hline & & New spaces & & & & & & & & \\
\hline & & Structure & & & & & & & & \\
\hline & & Landscape & & & & & & & & \\
\hline & & Orientation & & & & & & & & \\
\hline & & Ornaments & & & & & & & & \\
\hline & & Layout & & & & & & & & \\
\hline & & Symbols & & & & & & & & \\
\hline \multirow{7}{*}{ 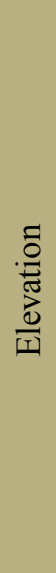 } & \multirow{4}{*}{ 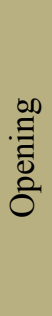 } & Entrance & & & & & & & & \\
\hline & & Windows & & & & & & & & \\
\hline & & $\begin{array}{l}\text { Ventilation } \\
\text { openings }\end{array}$ & & & & & & & & \\
\hline & & Perforated units & & & & & & & & \\
\hline & \multicolumn{2}{|c|}{ Color of elevation } & & & & & & & & \\
\hline & \multicolumn{2}{|r|}{ Heights } & & & & & & & & \\
\hline & \multicolumn{2}{|c|}{ Painting \& Decoration } & & & & & & & & \\
\hline
\end{tabular}




\section{Conclusions:}

- Anthropology is the most discipline which has presented culture as a valuable subject, where architecture is an important form of culture; as the main purpose of architecture can be defined as designing a building, which has a certain identity expressing its society's culture and civilization. This sort of architecture is valuable as it embodies both people's concepts and power along with the standardized functional needs.

- From ancient ages, people had applied anthropological aspects on their architecture, through respecting their environment, localities, beliefs, social relations, traditions (family, the position of woman, privacy...). This is clear in some architectural examples like the longhouse in America, the harem in Turkey, and moucharaby in Egypt.

- The success of anthropological guidelines that architect want to apply in buildings lies in its ability to be interpreted and understood so that it might be taken on a personal meaning for the users.

- Cultural anthropological studies proved that they are powerful tools can be used in design to represent practicalsocial-physiological-cultural situation into architecture.

- Throughout the twentieth-century architects have developed new or adapted existing design tools to create a built environment that responds to more than the physical needs of human beings. Architects have tried to deliver more than simple shelter that help people comprehend the world around them, inhabit it with some degree of dignity, and create ambitious design guidelines for the architectural profession.

- This study is devoted to present vernacular architecture as its main sort of architecture, which is excessively integrated with people, their environment, lifestyle, beliefs, and culture, and it varies according to the region in which this architecture locate. Also, the study highlighted that people still attached to this type of architecture, despite the great technologies and developments all over the world; because of the great relation between this architecture and people's culture, which is passed down from one generation to other, so new generations is psychologically attached to this architecture which expresses their parents and ancestors culture.

- The value of housing of displaced people in different countries that suffer from political disasters like wars or climatic disasters, in shelters provides them reassurance and comfort following often very traumatic times. As the needs change from saving lives to providing medium to long term shelter the construction of locally appropriate and accepted housing can be very important, where vernacular architecture can be the most appropriate and affordable solution.

- The major empirical outcome of the study is the determination of the way of design or understand architecture designed according to anthropological perspectives, you have to collect the majority of its historical documents, study their culture profoundly along with participation and observation of their daily activities and lifestyle, interviews with people live in the selected community and to collect archived data and photography.
- One of the most significant contributions of this study is that the methodology followed is flexible; this provides an opportunity to define a methodological approach that can be useful for many architects to use or analyze new communities representing people's identity and culture.

- The second major empirical outcome is the successful application of the theoretical-methodological approach. Through applying the theoretical conservation model for anthropological thinking on vernacular communities of North Africa and South Asia cultural region in contemporary terms, it was shown that it is possible to resolve problems in ways that can help the future development of the vernacular heritage.

- The study also makes contributions to approaches and practical methods for documenting vernacular constructions and the building technique know-how that produced them and finding future housing solutions that can connect the environment with its natural building materials to be used by the local community.

\section{Recommendations:}

Architects should add anthropological studies in the design process. Also to reuse the heritage and their local, traditional, or vernacular architecture as a valuable source of their architecture, to make architecture return back to people expressing their culture and identity. Also it recommends them to look seriously at creative solutions to protect the inherited vernacular architecture.

\section{References:}

[1] Dabaieh, M. (2011). "A future for the past of desert vernacular architecture" (Master thesis). Lund University, Lund, Sweden.

[2] Sharma, R. N. and Sharma, R. K. (1997). "Anthropology". New Delhi: Atlantic publishers and distributors, pp. 5-6.

[3] Hourigan, N. (2015). "Confronting classifications - When and what is vernacular architecture?" Journal of civil engineering and architecture, Vol. 3, No.1, pp.22-23.

[4] Rudolfsky, B. (1964). "Architecture without architects: A Short Introduction to Non-Pedigreed Architecture". New york: Museum of Modern Art, 2nd edition.

[5] Palmer, R \& Thérond, D. (2008). "The rural vernacular habitat: A heritage in our landscape". Futuropa for a new vision of landscape and territory: a Council of Europe Magazine. 1st edition, pp. 3-4.

[6] El Sammani, Mohamed. \& Salih, A. (2006). "Nomand's settlements in Sudan: Experiences, lessons and future action". Khartoum: United Nations Development Programme in Sudan, pp.2-5. 
[7] Venturi, R., Brown, D. \& Izenour, S. (1977). "Learning from Las Vegas: The forgotten symbolism of architectural form". MIT Press: Cambridge. The revised edition, pp. 134-137.

[8] Rapoport, A. (1969). "House form and culture". PrenticeHall, Englewood Cliffs: New Jersey. 10th edition, pp. 47.

[9] Alexander, C. (1964). "Notes on the synthesis of form". Cambridge: Harvard University Press. 7th edition, pp. 46-54.

[10] Guiodoni, E. (1978). "Primitive architecture". New York: Harry N. Abrams Inc. publishers, pp. 44-45.

[11] Denyer, S. (1978). "African traditional architecture". New York: Africa Publishing Co., pp.19.

[12] Hasabo, N. (2007). “Architecture and Folklore: Analytic Study of the Relation between Architecture and Folk Tradition with Concentration on Nuba" (Master Thesis). Cairo University, Cairo, Egypt, pp. 123.

[13] El-Gohary, M. "Al-Anthropologia: Osos nazaria w tatbekat amalia”. Cairo: Dar El-Maaref., pp.348-349.

[14] Berglee, R. (2012). "World Regional Geography: People, Places, and Globalization”. Boston: FlatWorld.

[15] https:/www.pinterest.com/pin/302726406181627115/ (27/1/2017).

[16] Wagih, E. (1991). “Al-Maana wa Al-omara: Manhag awali le al-tasmim el-benaay le al mogtmaat zat alseyakat al-thakafya al-motamayza" (Master Thesis). Cairo University, Cairo, Egypt, pp. 108.

[17] Fernea, R. (1978). "Nubian Ceremonial Life: Studies in Islamic Syncretism and Cultural Change". The American university in Cairo press: Cairo, pp. 15-16.

[18] Al-khadem, S. (1966). “Al-Fenon Al-shaabya Fe AlNuba”. Al-Dar al-masria le al-taalef w al-targama: Cairo, pp. 55.

[19] Hakim, O. (1999). "Nubian Architecture: The Egyptian vernacular experience". The Palm press: Cairo. Second edition.

[20] Sakr, M. (2015). " Traces of a vibrant Vernacular Nubian Architecture in Egypt". Maramures Vernadoc 2014: Maramures: Romania.

[21] Elcheikh, Z. (2016). "Cultural tourism between identity and income: The case of the Nubian village of Gharb Soheil”. Chronos: London. pp. 166.
[22] Ossama, A. (2002). "Sudan and Nubia". The Sudan Archaeological Research Society, Vol. 6, pp. 5961.

[23] Elcheikh, Z. (2016). "Cultural tourism between identity and income: The case of the Nubian village of Gharb Soheil". Chronos: London, pp. 166. 